\title{
Degassing Behavior of Nanostructured Al and Its Composites
}

\author{
ZHIHUI ZHANG, STEVEN DALLEK, RUSTIN VOGT, YING LI, TROY D. TOPPING, \\ YIZHANG ZHOU, JULIE M. SCHOENUNG, and ENRIQUE J. LAVERNIA
}

\begin{abstract}
The synthesis of bulk ultrafine-grained (UFG) and nanostructured Al via cryomilling can frequently require a degassing step prior to consolidation, partly due to the large surface area of the as-milled powders. The objective of this study is to investigate the effects associated with cryomilling with stearic acid additions (as a process-control agent) on the degassing behavior of $\mathrm{Al}$ powders. This objective was accomplished by completing select experiments with $\mathrm{Al}-7.5 \mathrm{Mg}$, Al-6.4 wt pet $\mathrm{Al}_{85} \mathrm{Ni}_{10} \mathrm{La}_{5}$, and $\mathrm{Al}-14.3$ wt pct $\mathrm{B}_{4} \mathrm{C}$. The interaction between $\mathrm{Al}$ and stearic acid was determined using thermal analysis combined with Fourier transform infrared spectroscopy (FTIR). The degassing experiments were carried out under high vacuum $\left(10^{-4}\right.$ to $\sim 10^{-6}$ torr $)$ in a range from room temperature to $400{ }^{\circ} \mathrm{C}$, with the pressure of the released gases monitored using a digital vacuum gage. The results showed that the liberation of chemisorbed water was suppressed in cryomilled Al powders and both the chemisorbed water and stearic acid were primarily released in the form of hydrogen. It was also demonstrated that under certain conditions, a nanostructure (grain size $\sim 100 \mathrm{~nm}$ ) can be retained following the hot vacuum degassing of cryomilled Al.
\end{abstract}

DOI: $10.1007 / \mathrm{s} 11661-009-0089-6$

(C) The Author(s) 2009. This article is published with open access at Springerlink.com

\section{INTRODUCTION}

ULTRAFINE-GRAINED (UFG) and nanostructured $\mathrm{Al}$ alloys (e.g., grain size 100 to $\sim 1000 \mathrm{~nm}$ ) produced via cryomilling have attracted considerable interest in the past decade due to their reported high room-temperature strength, high specific strength, and enhanced high-strain-rate properties. ${ }^{[1,2]}$ The observed improvements in mechanical response over those of conventional materials are in general attributed to various mechanisms, including: microstructural refinement (i.e., Hall-Petch strengthening), extended solid solubility, the presence of nonequilibrium structures (e.g., twins), and Orowan strengthening due to the presence of nanoscale secondary dispersoids. Cryomilled powders typically require a degassing procedure prior to consolidation into bulk form, in order to minimize the presence of hydrogen and hydrated compounds (e.g., $\mathrm{Al}_{2} \mathrm{O}_{3} \cdot 3 \mathrm{H}_{2} \mathrm{O}$ ) that are adsorbed on the powder. Moreover, the degassing conditions (e.g., temperature, time, and vacuum level) must be selected so as to retain the original microstructure to the extent possible.

It is well established that the presence of entrapped gases in powder metallurgy (PM) $\mathrm{Al}$ alloys can lead to cracking of the compact during thermomechanical

ZHIHUI ZHANG and YING LI, Postdoctoral Researchers, RUSTIN VOGT and TROY D. TOPPING, Graduate Student Researchers, YIZHANG ZHOU, Associate Researcher, JULIE M. SCHOENUNG, Professor, and ENRIQUE J. LAVERNIA, Distinguished Professor, are with the Department of Chemical Engineering and Materials Science, University of California, Davis, CA 95616. Contact e-mail: zhizhang@ucdavis.edu STEVEN DALLEK, Research Scientist, formerly with the Naval Surface Warfare Center, Carderock Division, West Bethesda, MD 20817, is with G/J Associates, Annapolis, MD 21401.

Manuscript submitted July 20, 2009.

Article published online November 6, 2009 processing or can result in the formation of blisters that severely degrade ductility. Reduction of the gas content in Al alloy powders prior to compaction is, therefore, critically important. ${ }^{[3-6]}$ Thermodynamic calculations reveal that it is practically impossible to produce oxide-free powder because in the Al-O system, the partial pressure of $\mathrm{O}_{2}$ in equilibrium with $\mathrm{Al}_{2} \mathrm{O}_{3}$ is far below the range attainable under protective gases or in vacuum systems (Al oxide requires an oxygen partial pressure of $10^{-144} \mathrm{~atm}$ at $100^{\circ} \mathrm{C}$ and $10^{-64} \mathrm{~atm}$ at $\left.500{ }^{\circ} \mathrm{C}^{[7]}\right)$. Consequently, oxidation always takes place on the fresh surface of Al powders. Furthermore, oxide formation is associated with a fast kinetic process ${ }^{[8]}$ and the oxide layer exhibits a strong tendency for hydration reactions when exposed to humid environments. ${ }^{[9]}$ Accordingly, $\mathrm{Al}$ alloy powder is in general covered with an oxide layer bonded with chemisorbed water $\left(\mathrm{Al}_{2} \mathrm{O}_{3}\right.$. $\left.3 \mathrm{H}_{2} \mathrm{O}\right)$ and physisorbed water $\left(\mathrm{H}_{2} \mathrm{O}\right) \cdot{ }^{[3,9]}$ For gas-atomized powders, high-temperature degassing has been investigated in $\mathrm{Al}$ alloys such as $\mathrm{Al}-\mathrm{Zn}-\mathrm{Mg}-\mathrm{Cu}-\mathrm{Co}(\mathrm{Al}$ 7091), ${ }^{[3,10,11]}$ Al-Si-Cu-Mg-Fe, ${ }^{[12,13]}$ Al-Fe-Mo-Zr, ${ }^{[12]}$ and Al-Fe-Mg alloys. ${ }^{[14]}$ Although there is wide variation in alloy composition and production conditions, the reaction that occurs as the degassing temperature increases shows two typical peaks: at temperatures up to $\sim 350{ }^{\circ} \mathrm{C}$, decomposed water vapor is the predominant species outgassed, whereas hydrogen generation becomes dominant at higher temperatures $\left(-350{ }^{\circ} \mathrm{C}\right.$ to $450{ }^{\circ} \mathrm{C}$ ), as illustrated schematically in Figure 1. The evaporation of the physisorbed water is regarded as occurring at temperatures less than $175^{\circ} \mathrm{C} .{ }^{[9]}$

A review of the published literature shows that systematic study of the degassing behavior of cryomilled powder has heretofore never been reported, despite the fact that it is almost always used prior to the consolidation of nanostructured and other types of 


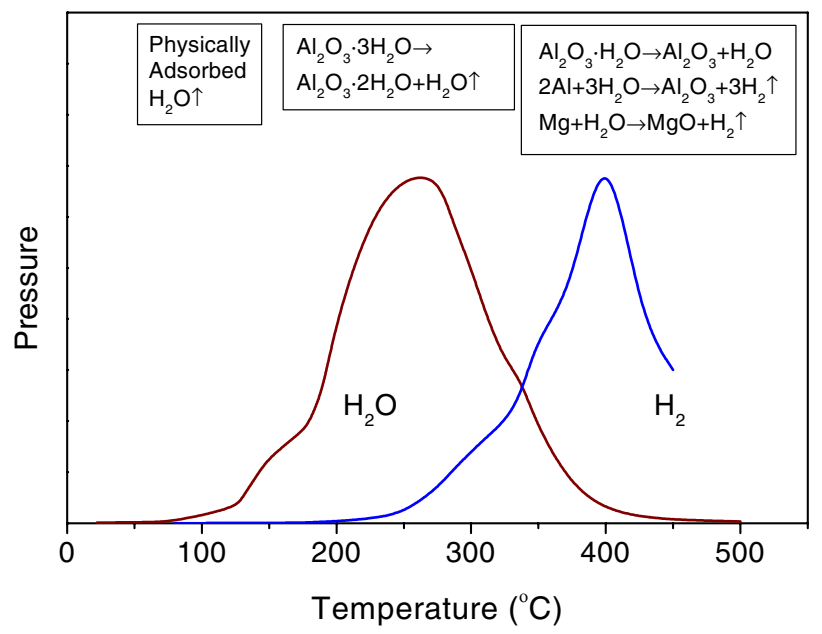

Fig. 1-Degassed species in $\mathrm{Al}$ alloys as a function of temperature.

powders. To that end, it is important to consider several factors. First, stearic acid (e.g., octadecanoic acid $\left.\mathrm{CH}_{3}\left(\mathrm{CH}_{2}\right)_{16} \mathrm{COOH}\right)$ is generally added as a processingcontrol agent to prevent extensive cold welding between $\mathrm{Al}$ powders as well as between the $\mathrm{Al}$ powders and milling media (balls, impeller, and vessel) during the cryomilling process; it is important to remove the incorporated hydrogen during degassing, because it will adversely affect the ductility of the consolidated material. ${ }^{[10]}$ Second, although an initial Al hydroxide layer $\left(\mathrm{Al}_{2} \mathrm{O}_{3} \cdot 3 \mathrm{H}_{2} \mathrm{O}\right)$ that forms on the surface of the feedstock powder fractures and becomes embedded in the particle interior during cryomilling, a new oxide layer may reform on the fresh surface during powder transport and storage following cryomilling. This often leads to an increase in the hydroxide content in cryomilled $\mathrm{Al}$ powder. For example, the oxygen in cryomilled Al alloys has been reported to be in the range of 0.3 to $\sim 1.5 \mathrm{wt} \mathrm{pet},{ }^{[1]}$ which is equivalent to 0.4 to $\sim 2 \mathrm{vol} \mathrm{pct}$ oxides, whereas the surface oxide accounts for less than $\sim 0.6$ vol pet in the product of PM Al alloys produced directly from atomized powders. ${ }^{[14]}$ Third, for PM Al composites produced via cryomilling, the introduction of a dissimilar phase can greatly alter the repeated deformation, cold-welding, and fracture process during mechanical milling, resulting in different powder-specific surfaces. ${ }^{[15]}$ Thus, unlike the direct mixing of the conventional $\mathrm{Al}$ and reinforcement powder, the degassing behavior of the cryomilled nanocomposite powder needs to be addressed separately. In view of these arguments, in this work, the degassing behavior of the following cryomilled powders was investigated in detail: (1) Al-7.5Mg alloy, (2) Al-6.4 wt pet $\mathrm{Al}_{85} \mathrm{Ni}_{10} \mathrm{La}_{5}$, and (3) $\mathrm{Al}-14.3$ wt pet $\mathrm{B}_{4} \mathrm{C}$ nanocomposite powder.

\section{EXPERIMENTAL}

\section{A. Materials}

Gas-atomized $\mathrm{Al}$ (99.7 pet purity) and $\mathrm{Al}-7.5 \mathrm{Mg}$ powders produced by Valimet, Inc. (Stockton, CA) were the primary feedstock material used in this study. The particle size of the Al powder was less than $\sim 90 \mu \mathrm{m}$ and that of the Al-7.5Mg powder less than $45 \mu \mathrm{m}$. Two types of reinforcement particles with different initial sizes were selected in the study, i.e., $\mathrm{B}_{4} \mathrm{C}(1$ to $7 \mu \mathrm{m})$ and amorphous $\mathrm{Al}_{85} \mathrm{Ni}_{10} \mathrm{La}_{5}(<25 \mu \mathrm{m})$, owing to the fact that the specific area of composite powders produced by mechanical milling depends on the tendency for fragmentation in the reinforcement particles. ${ }^{[15]}$ The $\mathrm{B}_{4} \mathrm{C}$ powder was supplied by TETRABOR* Boron Carbide.

*TETRABOR is a registered trademark of ESK Ceramics GmbH \& Co. KG, Kempten, Germany.

The $\mathrm{Al}_{85} \mathrm{Ni}_{10} \mathrm{La}_{5}$ powder was produced with in-house equipment via argon atomization. Powder particles in the range of $<25 \mu \mathrm{m}$, determined to be fully amorphous by X-ray diffraction (XRD), were mechanically sieved for blending with the feedstock Al powder.

To study degassing behavior and provide insight into possible interactions between stearic acid and the oxide phases of Al powder, experiments were completed with $\mathrm{Al}_{2} \mathrm{O}_{3}$ (99.99 pct purity, $\sim 5-\mu \mathrm{m}$ particle size) and $\mathrm{MgO}$ (99.95 pct purity, $\sim 10-\mu \mathrm{m}$ particle size), which were supplied by Cerac, Inc. (Milwaukee, WI).

\section{B. Cryomilling}

Cryomilling was carried out in a liquid nitrogen slurry in a modified Union Process 1-S Szegvari attritor (Union Process Inc., Akron, OH) with a stainless steel vessel and balls ( $\sim 6.4 \mathrm{~mm}$ in diameter). The attritor was operated at a rotation rate of $180 \mathrm{rpm}$ at a temperature of approximately $-185^{\circ} \mathrm{C}$. A ball-to-powder ratio of $32: 1$, with 0.2 wt pet stearic acid, was added as a process-control agent to control the cold-welding process. For the Al-7.5Mg alloy, $1 \mathrm{~kg}$ of powder was charged into the vessel and cryomilled for 8 hours; previous studies have shown that the grain size after 8 hours of cryomilling approached the minimum grain size achievable $(\sim 25 \mathrm{~nm}) \cdot{ }^{[16]}$ For the $\mathrm{Al}-14.3 \mathrm{wt}$ pct $\mathrm{B}_{4} \mathrm{C}$ and Al-6.4 wt pet $\mathrm{Al}_{85} \mathrm{Ni}_{10} \mathrm{La}_{5}$ composites, $1 \mathrm{~kg}$ of $\mathrm{Al}$ and the reinforcement powder with the appropriate weight ratio were blended in a V-type blender for 4 hours prior to cryomilling. For either of the composite powders, the milling time was selected to be 12 hours to ensure a completely homogeneous distribution of the reinforcement phase in the $\mathrm{Al}$ matrix phase. Following cryomilling, the cryomilled powder was transferred and stored in a nitrogen glove box.

\section{Degassing}

An Al 6061 can $(33 \mathrm{~mm}$ in diameter by $70 \mathrm{~mm}$ in length) was filled with powder $(\sim 90 \mathrm{~g})$, and then placed into a tube furnace and connected to a vacuum system equipped with a Varian Turbo-V70 turbopump (Varian, Inc., Lexington, MA), which was backed by a roughing rotary pump. Prior to filling the can, the can was helium leak checked to ensure against contamination during 


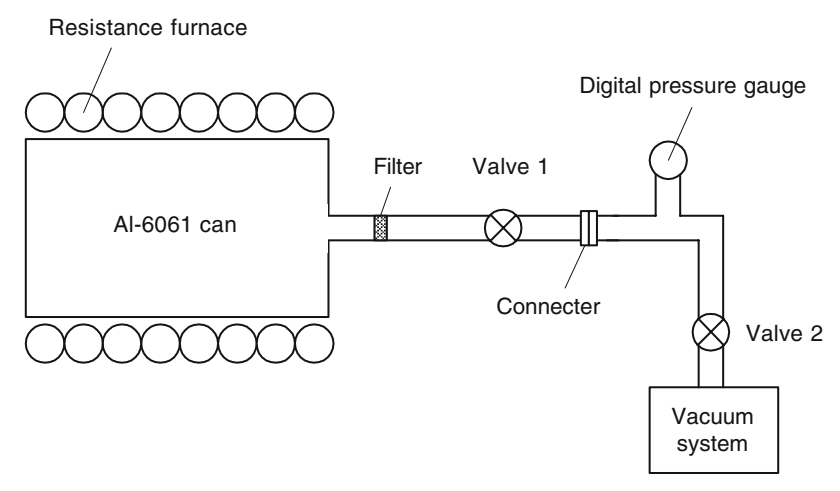

Fig. 2-Schematic of the degassing apparatus.

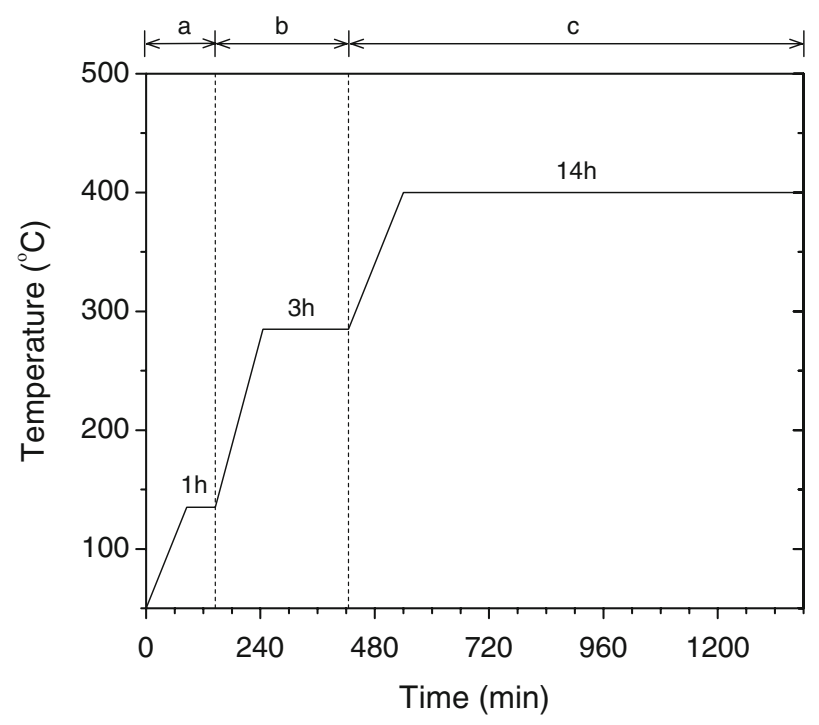

Fig. 3-Time-temperature degassing profile.

degassing. The degassing apparatus is illustrated in Figure 2. To prevent air contact, the powder handling was conducted in the nitrogen glove box in which the cryomilled powder was stored. The oxygen and moisture level were kept at less than $1 \mathrm{ppm}$ in the glove box. A vacuum valve (valve 1) was attached to the can and closed before removing the filled can from the glove box.

Prior to heating, the can was pumped for approximately 2 hours until a pressure of $<5 \times 10^{-6}$ torr was reached. With the objective of studying the pressure changes that occur during the evolution of the various species (i.e., physisorbed water, chemisorbed water, and hydrogen), samples were degassed at $135^{\circ} \mathrm{C}, 285^{\circ} \mathrm{C}$, and $400{ }^{\circ} \mathrm{C}$, as depicted in Figure 3 by stages (a), (b), and (c). The holding time at stage (a) (1 hour) and stage (b) (3 hours) was determined by the appearance of a maximum, while the holding time at stage (c) ( $\sim 14$ hours) was determined when the vacuum reading returned to $10^{-6}$ torr. The samples, still maintained under high-vacuum conditions, were then cooled to room temperature for chemical and microstructural characterization studies.

\section{Thermal Analysis}

Differential scanning calorimetry (DSC), thermogravimetric analysis (TGA), and Fourier transform infrared spectroscopy (FTIR) were used to study the interactions between the process-control agent (stearic acid) and the Al alloy powders. The DSC experiments were carried out in a TA Instruments 2920 (TA Instruments, New Castle, DE) DSC module, using nitrogen as the purging gas. The TGA experiments were conducted using a TA Instruments 951 TGA module. Samples were heated in a platinum boat in a flowing atmosphere of nitrogen. In the TGA/FTIR experiments, the TGA was interfaced to a Nicolet 510P FTIR (Nicolet Instruments, Madison, WI). The TGA and FTIR instruments were first purged with nitrogen to remove air and to obtain the FTIR background spectrum. The nitrogen purge was maintained until the temperature reached $100{ }^{\circ} \mathrm{C}$ (well below the initial weight-loss temperature) to keep air out of the system and was then turned off while the stearic acid sample vaporized. When the sample was completely vaporized, the purge gas was then turned on to transfer all of the evolved gas to the FTIR instrument.

\section{E. Microstructure and Chemistry Characterization}

The atomized and cryomilled powders were characterized using XRD and scanning electron microscopy (SEM). The XRD was carried out in a Scintag XDS 2000 (Scintag Inc., Cupertino, CA) X-ray diffractometer using $\mathrm{Cu} K_{\alpha}$ radiation. The SEM was performed in an FEI XL-30 FEG (FEI Company, Hillsboro, OR) scanning electron microscope. Chemical analysis was conducted by $\mathrm{LECO}^{* *}$ using the combustion-infrared

**LECO is a trademark of LECO Corporation, St. Joseph, MI.

detection method for C (CS600), the inert gas fusionthermal conductivity detection for H (RHEN 602), and the inert gas fusion-infrared detection method for $\mathrm{O}$ (TCH600).

\section{RESULTS}

\section{A. Stearic Acid Desorption from Mixtures with Al and Its Oxides}

The desorption of stearic acid at elevated temperatures, which was in contact with $\mathrm{Al}$ powder, was studied by DSC, TGA, and FTIR. First, it is necessary to determine whether the stearic acid decomposes at elevated temperatures. Figure 4 shows the DSC continuous tracing curve of stearic acid. Approximately $1.5 \mathrm{mg}$ of stearic acid was encapsulated in a hermetically sealed DSC pan with a pinhole in the lid and heated from $20{ }^{\circ} \mathrm{C}$ to $480{ }^{\circ} \mathrm{C}$ at a rate of $10{ }^{\circ} \mathrm{C} / \mathrm{min}$. The small endotherm at approximately $60{ }^{\circ} \mathrm{C}$ is attributed to the melting of an impurity, possibly present in the pan or in the compound, but is not thought to be relevant to the current results. The large endotherm, with an onset 


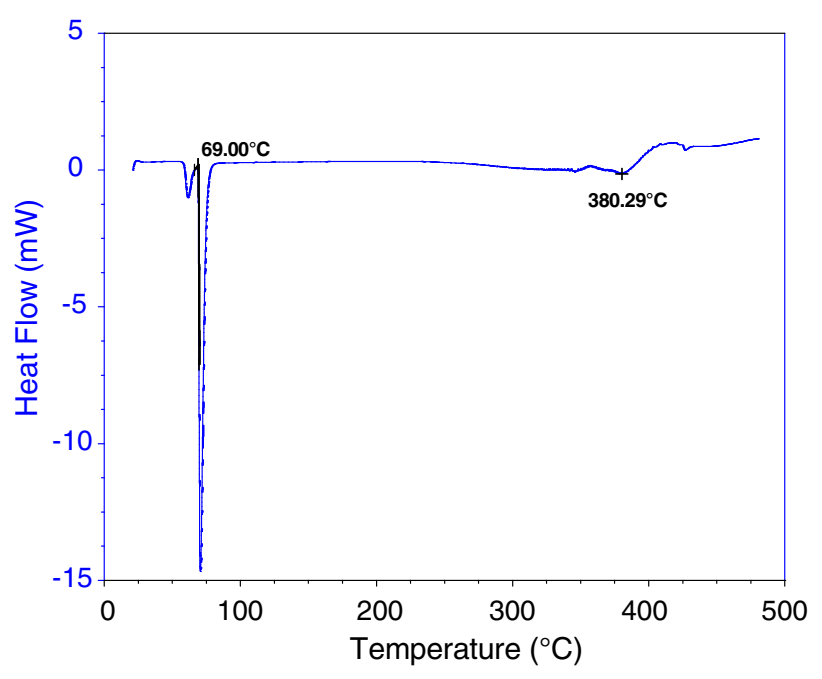

Fig. 4-DSC curve of stearic acid.

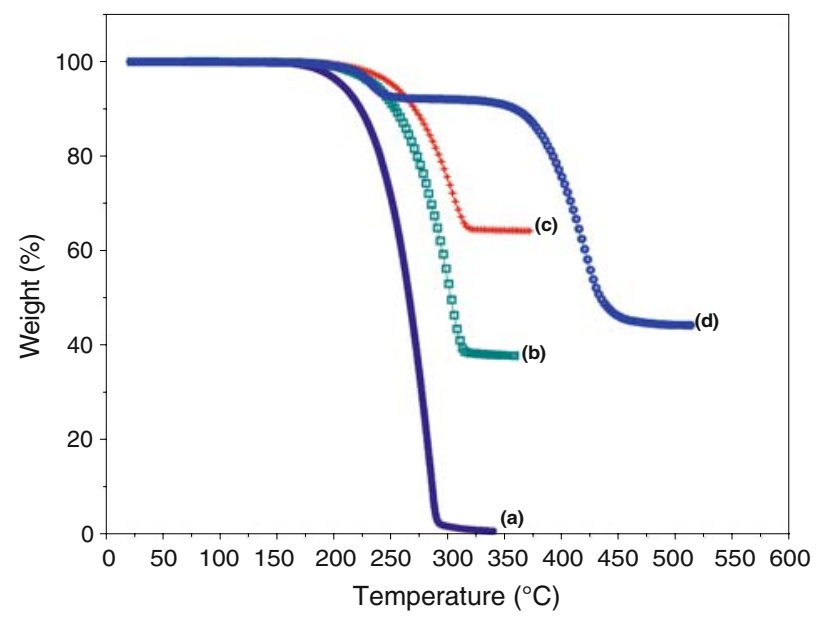

Fig. 5-TGA curves of (a) stearic acid, (b) stearic acid $+\mathrm{Al}$, (c) stearic acid $+\mathrm{Al}_{2} \mathrm{O}_{3}$, and (d) stearic acid $+\mathrm{MgO}$.

temperature of $69^{\circ} \mathrm{C}$, is attributed to the melting of stearic acid (Merck Index: melting point $69^{\circ} \mathrm{C}$ to $70{ }^{\circ} \mathrm{C}$ ). Note that there are no further thermal events from $70{ }^{\circ} \mathrm{C}$ to $\sim 380{ }^{\circ} \mathrm{C}$. The small endotherm at approximately $380{ }^{\circ} \mathrm{C}$ is in good agreement with the literature values for the boiling point of stearic acid (Merck Index: $383{ }^{\circ} \mathrm{C}$ ). The erratic thermal behavior above $380{ }^{\circ} \mathrm{C}$ is caused by vapor exiting the pan through the pinhole. The evolved gaseous phase from stearic acid was determined by simultaneous TGA/FTIR measurements. Figure 5(a) shows the TGA curve of stearic acid at a heating rate of $30{ }^{\circ} \mathrm{C} / \mathrm{min}$. The sample begins to volatilize above approximately $150{ }^{\circ} \mathrm{C}$, and the process is complete by $\sim 280^{\circ} \mathrm{C}$. Note that the slow vaporization of stearic acid from approximately $150{ }^{\circ} \mathrm{C}$ to $280{ }^{\circ} \mathrm{C}$ in the TGA experiment is suppressed in the DSC experiment by encapsulating the sample in a sealed DSC cup with a pinhole in the lid. The FTIR spectrum of the evolved gas is shown in Figure 6(a). The FTIR detected seven predominant bands that are found in stearic

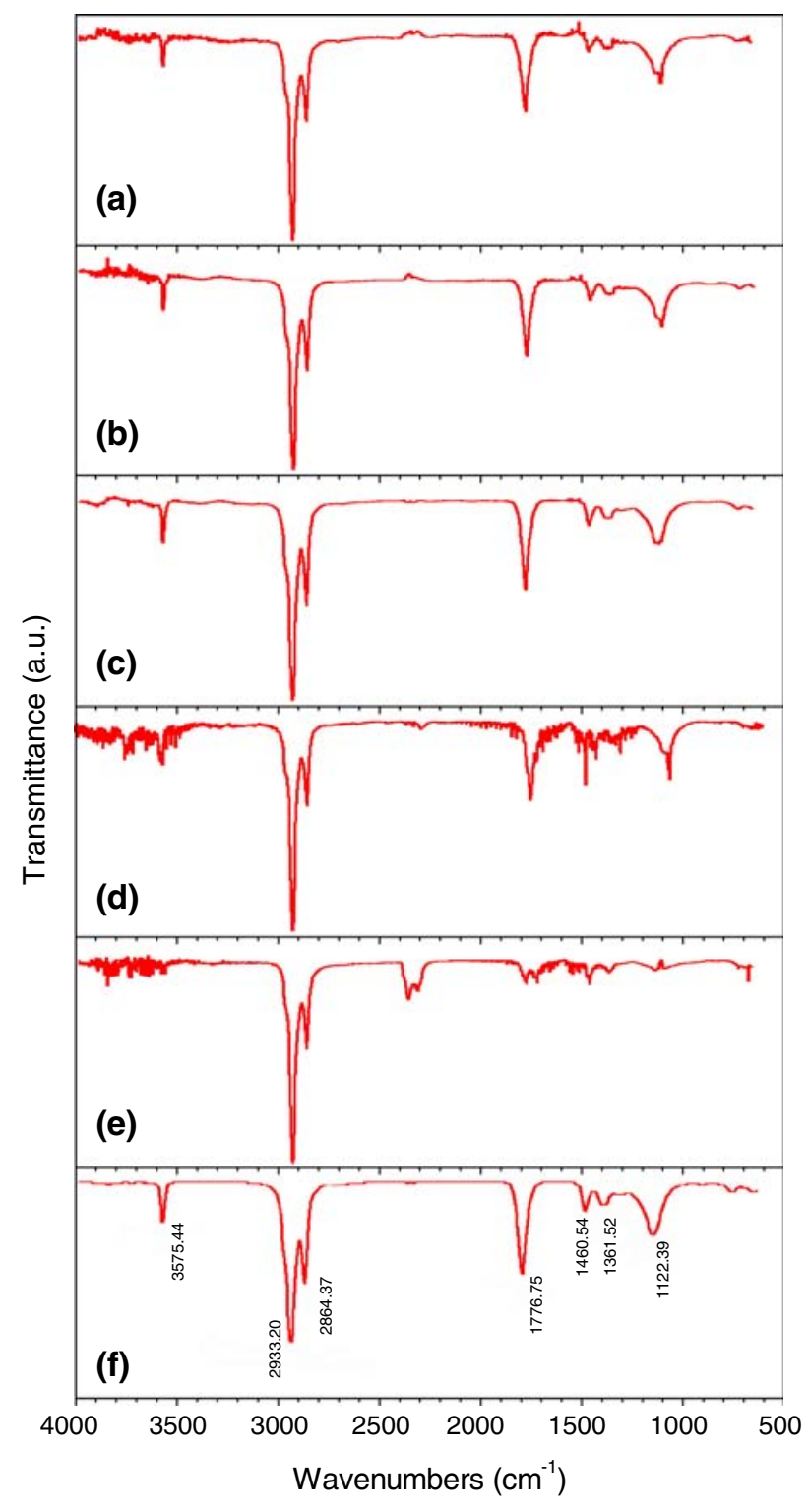

Fig. 6-FTIR spectra of evolved gas from TGA experiments: (a) stearic acid, (b) stearic acid $+\mathrm{Al},(c)$ stearic acid $+\mathrm{Al}_{2} \mathrm{O}_{3},(d)$ stearic acid $+\mathrm{MgO}\left(200{ }^{\circ} \mathrm{C}\right.$ to $\left.250{ }^{\circ} \mathrm{C}\right)$, (e) stearic acid $+\mathrm{MgO}\left(350{ }^{\circ} \mathrm{C}\right.$ to $450{ }^{\circ} \mathrm{C}$ ), and $(f)$ stearic acid spectrum (Nicolet Vapor Phase Library).

acid. ${ }^{[17-19]}$ For example, the 2932 and $2863 \mathrm{~cm}^{-1}$ bands are assigned to the asymmetric and symmetric stretching vibrations, respectively, of the methylene groups $\left(\mathrm{CH}_{2}\right)$ of the aliphatic chain, and band $1777 \mathrm{~cm}^{-1}$ is assigned to the carbonyl stretching. Band $1462 \mathrm{~cm}^{-1}$ is attributed to the deformation of methylene groups and $1367 \mathrm{~cm}^{-1}$ to the symmetric deformation of the methyl group $\left(\mathrm{CH}_{3}\right)$. Band $1113 \mathrm{~cm}^{-1}$ closely matches the wag and twist modes of the methylene group. As a comparison, the spectrum in Figure 6(a) is also in excellent agreement with the stearic acid library spectrum (Nicolet Vapor Phase Library (Figure 6(f)).

Next, the desorption of stearic acid from commercially pure $\mathrm{Al}$ powder was investigated. The TGA/FTIR experiments were carried out with a similar procedure, 
except that sample pellets were blended from stearic acid/Al powder to achieve intimate contact. The TGA curve of a stearic acid/Al mixture is shown in Figure 5(b). The theoretical and experimental weight losses are virtually identical. The FTIR spectrum of the evolved gas (Figure 6(b)) is identical to that of stearic acid. As mentioned previously, Al powder is usually coated with a thin oxide layer. Hence, the desorption of stearic acid from $\mathrm{Al}_{2} \mathrm{O}_{3}$ powder was also analyzed. The TGA curve of a stearic acid $/ \mathrm{Al}_{2} \mathrm{O}_{3}$ mixture is shown in Figure 5(c). Again, the theoretical and experimental weight losses are in excellent agreement and the FTIR spectrum (Figure 6(c)) shows that the only evolved gas is stearic acid. These results show that there is no reaction between stearic acid and either pure $\mathrm{Al}$ or $\mathrm{Al}_{2} \mathrm{O}_{3}$ under the present TGA experimental conditions.

Third, the desorption of stearic acid from $\mathrm{MgO}$ was considered, because $\mathrm{Mg}$ is a common alloying element in $\mathrm{Al}$ alloys and the affinity of $\mathrm{Mg}$ to $\mathrm{O}$ is higher than that of $\mathrm{Al}$ to $\mathrm{O}{ }^{[7]}$ Accordingly, $\mathrm{MgO}$ is also encountered in the surface oxides. ${ }^{[3,14]}$ The TGA curve of a stearic acid/ $\mathrm{MgO}$ mixture is shown in Figure 5(d). There is clear evidence of a reaction between stearic acid and $\mathrm{MgO}$, based on the appearance of a new, low-temperature weight-loss plateau in the temperature range $200{ }^{\circ} \mathrm{C}$ to $250{ }^{\circ} \mathrm{C}$. The corresponding FTIR spectrum (Figure 6(d)) shows the presence of water, which may evolve according to the following reaction, to form magnesium stearate:

$$
\begin{aligned}
& 2 \mathrm{CH}_{3}\left(\mathrm{CH}_{2}\right)_{16} \mathrm{COOH}+\mathrm{MgO} \\
& \quad \rightarrow 2\left[\mathrm{CH}_{3}\left(\mathrm{CH}_{2}\right)_{16} \mathrm{COO}\right] \mathrm{Mg}+\mathrm{H}_{2} \mathrm{O} \uparrow
\end{aligned}
$$

Note that the TGA weight plateau and the weight loss predicted by this equation do not agree, and the FTIR spectrum clearly shows the evolution of stearic acid gas in addition to water, suggesting that this reaction might proceed partially under the given conditions. At higher temperatures $\left(350{ }^{\circ} \mathrm{C}\right.$ to $\left.450{ }^{\circ} \mathrm{C}\right)$, the FTIR spectrum (Figure 6(e)) shows the presence of evolved carbon dioxide, an expected decomposition product of the stearate.

\section{B. Adsorption of Stearic Acid during Cryomilling}

The introduction of stearic acid represents a significant source of hydrogen in cryomilled Al alloy powders. However, a TGA scan of cryomilled Al with the normal addition of $0.2 \mathrm{wt}$ pct stearic acid was not able to detect any weight loss. To determine whether stearic acid is chemically or physically adsorbed during cryomilling, $2 \mathrm{wt}$ pct stearic acid was added to the starting powder and then cryomilled for a short time ( 2 hours). The cryomilled powders were then heated in a platinum boat at a rate of $10{ }^{\circ} \mathrm{C} / \mathrm{min}$. The TGA results are shown in Figure 7. Weight losses of 1.12 and 1.27 pct, respectively, are recorded in two different samples. The different TGA weight losses as a function of temperature in different samples suggest that these materials may contain chemisorbed as well as physisorbed species. Furthermore, some weight losses may also be attributed to the decomposition of stearic acid. Because the TGA sample boat could accommodate only approximately

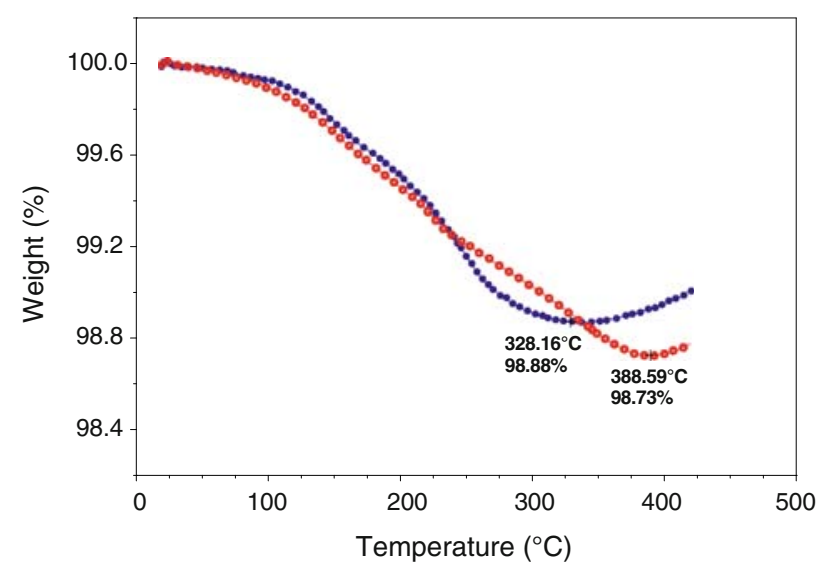

Fig. 7-TGA curves for cryomilled Al powders with addition of $2 \mathrm{wt}$ pct stearic acid.

$10 \mathrm{mg}$ of the low-density cryomilled powder, however, the concentration of evolved gases was insufficient for FTIR analysis.

\section{Degassing of Cryomilled Powder}

An initial vacuum level of $<5 \times 10^{-6}$ torr was achieved at room temperature before starting the degassing procedure. The heating program is depicted in Figure 3. In stage (a), the sample was heated to $135^{\circ} \mathrm{C}$ at a heating rate of $1{ }^{\circ} \mathrm{C} / \mathrm{min}$ and evacuated for 1 hour at this temperature; still under high vacuum, the sample was then heated at a heating rate of $1.5^{\circ} \mathrm{C} / \mathrm{min}$ to $285^{\circ} \mathrm{C}$ and held for 3 hours (stage (b)); in stage (c), the sample was heated to $400{ }^{\circ} \mathrm{C}$ at a heating rate of $1{ }^{\circ} \mathrm{C} / \mathrm{min}$ and held at this temperature until the vacuum level again reached the $10^{-6}$-torr range (i.e., 14 hours). The change in pressure as a function of time is shown in Figure 8(a). In the case of the cryomilled Al-7.5Mg sample, a peak was clearly resolved in stage (a), suggesting that the physisorbed water was not fully released by evacuating at room temperature. The peak in stage (b) agreed well with the temperature range provided in the literature for the release of chemisorbed water. $^{[3,13,20]}$ For comparison, the pressure-vs-time curve for the atomized $\mathrm{Al}-7.5 \mathrm{Mg}$ was also plotted in Figure $8(\mathrm{a})$. Note that the atomized $\mathrm{Al}-7.5 \mathrm{Mg}$ powder showed a much stronger release of both physisorbed and chemisorbed water when compared to the cryomilled $\mathrm{Al}-7.5 \mathrm{Mg}$ powder. However, in stage (c), in which hydrogen was the dominant outgassing species, the peak intensity for cryomilled powder became much stronger than that for the atomized powder. The reverse of the intensities for the low- and high-temperature peaks in the cryomilled sample suggest that the major outgassing event is shifted to higher temperatures and the major outgassing species is evolved in the form of hydrogen, as a result of cryomilling.

Figure $8(\mathrm{~b})$ shows the change in pressure as a function of time for the cryomilled Al-6.4 wt pet $\mathrm{Al}_{85} \mathrm{Ni}_{10} \mathrm{La}_{5}$ and Al-14.3 wt pet $\mathrm{B}_{4} \mathrm{C}$ nanocomposite powders, which were degassed with the same temperature profile, as depicted in Figure 3. As a reference, the pressure- $v s$-time 


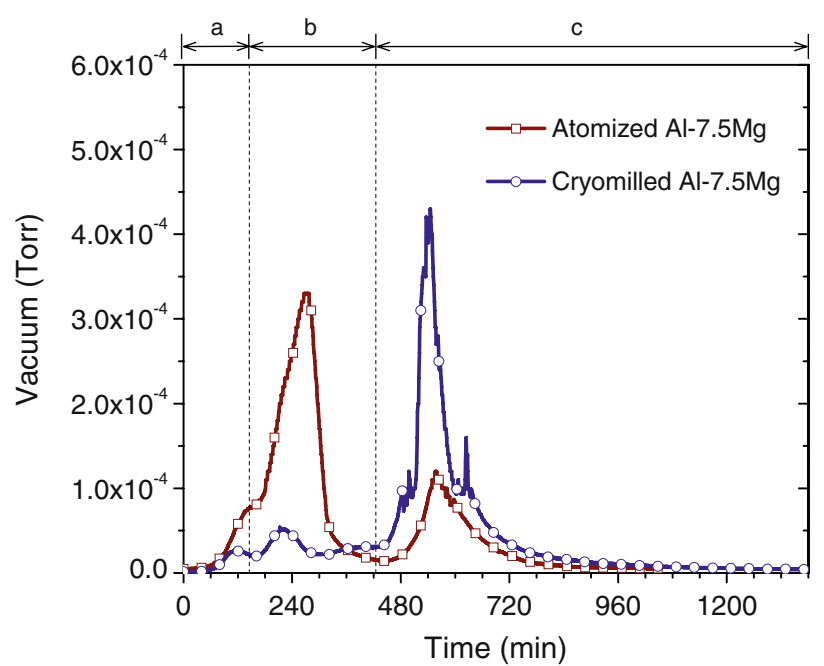

(a)

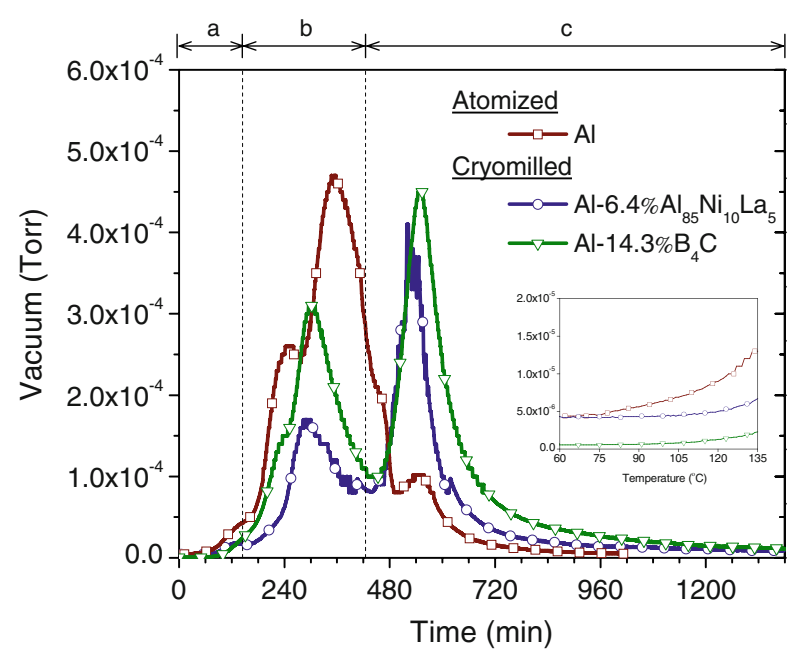

(b)

Fig. 8-Degassing curves for cryomilled $(a) \mathrm{Al}-7.5 \mathrm{Mg}$ and $(b)$ Al-6.4 wt pet $\mathrm{Al}_{85} \mathrm{Ni}_{10} \mathrm{La}_{5}$ and Al-14.3 wt pet $\mathrm{B}_{4} \mathrm{C}$ powders, in comparison to atomized powders. Inset shows the degassing curve at low temperatures.

curve of the atomized $\mathrm{Al}$ (i.e., the matrix powder) is also plotted in Figure 8(b). Again, the cryomilled powder showed lower peak intensities for the release of physisorbed and chemisorbed water but a stronger peak for hydrogen release. It is worth noting that the pressure profile of the cryomilled Al-14.3 wt pct $\mathrm{B}_{4} \mathrm{C}$ sample is higher than that of the Al-6.4 wt pet $\mathrm{Al}_{85} \mathrm{Ni}_{10} \mathrm{La}_{5}$ sample. This behavior is a result of the different powder particle sizes and morphologies for the two composite powders after cryomilling. As shown in Figure 9, the cryomilled Al-14.3 wt pet $\mathrm{B}_{4} \mathrm{C}$ powder has a higher specific surface area than the cryomilled Al-6.4 wt pct $\mathrm{Al}_{85} \mathrm{Ni}_{10} \mathrm{La}_{5}$ powder.

\section{Chemical Analysis of Degassed Powder}

The reduction of impurity species $\mathrm{C}, \mathrm{H}$, and $\mathrm{O}$ after degassing was studied by chemical analysis. The chemical

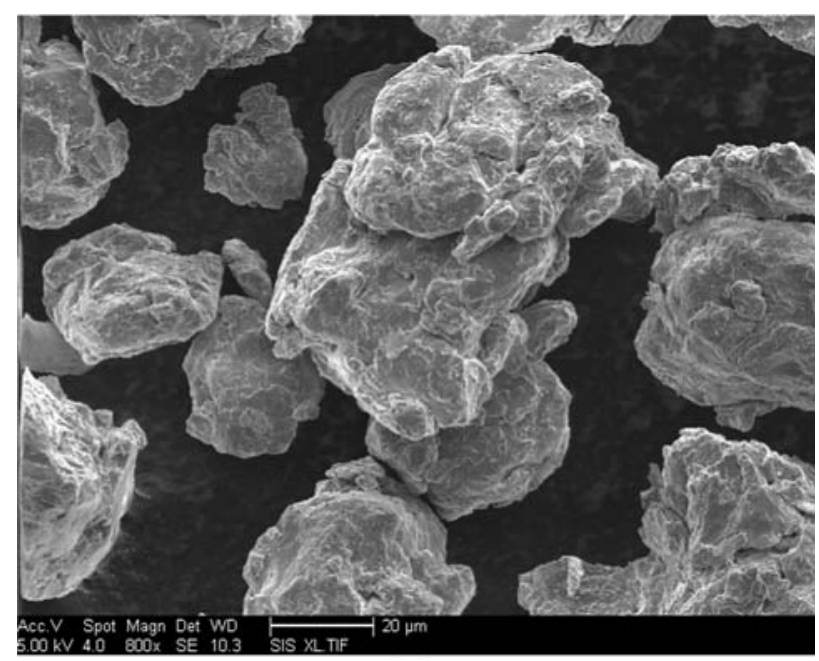

(a)

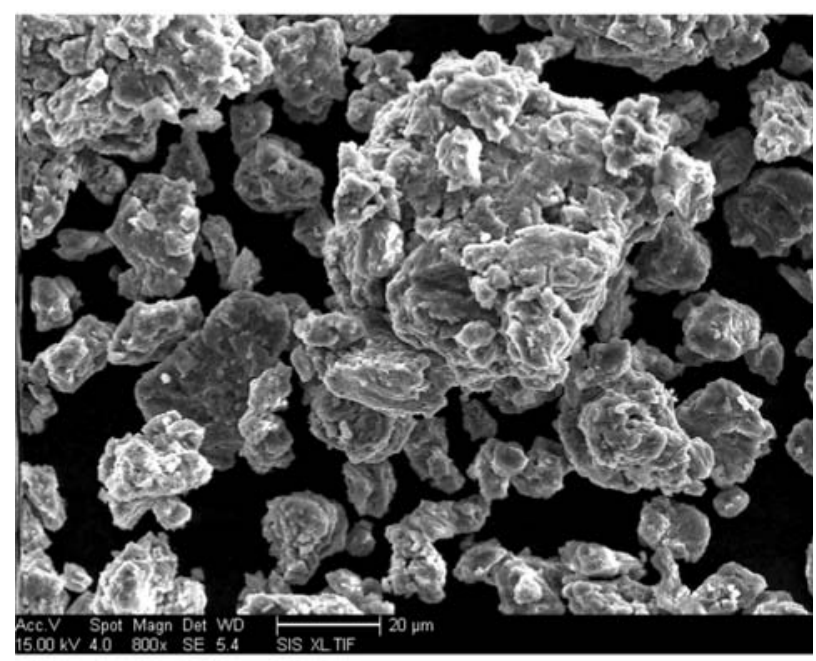

(b)

Fig. 9-SEM images of cryomilled (a) Al-6.4 wt pet $\mathrm{Al}_{85} \mathrm{Ni}_{10} \mathrm{La}_{5}$ and (b) $\mathrm{Al}-14.3 \mathrm{wt}$ pet $\mathrm{B}_{4} \mathrm{C}$.

analysis results are listed in Table I. In the as-received atomized pure-Al powder, the $\mathrm{O}, \mathrm{H}$ and $\mathrm{C}$ contents were $0.374,0.0193$, and $0.0031 \mathrm{wt}$ pct, respectively; in the as-received atomized $\mathrm{Al}-7.5 \mathrm{Mg}$ powder, the $\mathrm{O}, \mathrm{H}$, and $\mathrm{C}$ contents were $0.107,0.0142$, and $0.0172 \mathrm{wt}$ pct, respectively. The $\mathrm{O}$ and $\mathrm{H}$ contents in the as-received atomized Al powder were higher than those of the as-received atomized $\mathrm{Al}-7.5 \mathrm{Mg}$ powder, suggesting that the as-received atomized Al powder contained a higher volume of surface hydroxides; this may account for the different profile of water evolution during stage (b) for the as-received atomized $\mathrm{Al}$ and $\mathrm{Al}-7.5 \mathrm{Mg}$ powder, as shown in Figures 8(a) and (b). Following cryomilling, the $\mathrm{O}, \mathrm{H}$, and $\mathrm{C}$ contents were increased. It is worth noting that the reinforcement phase addition itself was not a significant source of the $\mathrm{O}$ and $\mathrm{H}$ pickup. For example, the $\mathrm{O}$ and $\mathrm{H}$ content in the atomized $\mathrm{Al}_{85} \mathrm{Ni}_{10} \mathrm{La}_{5}$ powder is less than that in the as-received atomized pure $\mathrm{Al}$ powder. Therefore the $\mathrm{O}, \mathrm{H}$, and $\mathrm{C}$ pickup was ascribed to a characteristic of the handling 
Table I. C, H, and O Content in Atomized and Cryomilled Al Powders

\begin{tabular}{|c|c|c|c|c|c|c|}
\hline Condition & Process & Material & Designation & $\mathrm{C}$ & $\mathrm{H}$ & $\mathrm{O}$ \\
\hline \multirow[t]{5}{*}{ As-received } & atomized & $\mathrm{Al}-7.5 \mathrm{Mg}$ & M1 & 0.0172 & 0.0142 & 0.107 \\
\hline & & $\mathrm{Al}$ & Al & 0.0031 & 0.0193 & 0.374 \\
\hline & & $\mathrm{Al}_{85} \mathrm{Ni}_{10} \mathrm{La}_{5}$ & - & - & 0.0071 & 0.194 \\
\hline & cryomilled & $\mathrm{Al}-7.5 \mathrm{Mg}$ & M2 & 0.17 & 0.0485 & 0.304 \\
\hline & & Al-6.4 pct $\mathrm{Al}_{85} \mathrm{Ni}_{10} \mathrm{La}_{5}$ & $\mathrm{~A} 2$ & 0.162 & 0.0432 & 0.57 \\
\hline \multirow[t]{4}{*}{ Degassed } & atomized & $\mathrm{Al}-7.5 \mathrm{Mg}$ & DM1 & 0.02 & 0.0109 & 0.102 \\
\hline & cryomilled & $\mathrm{Al}-7.5 \mathrm{Mg}$ & DM2 & 0.169 & 0.0098 & 0.328 \\
\hline & & Al-6.4 pct $\mathrm{Al}_{85} \mathrm{Ni}_{10} \mathrm{La}_{5}$ & DA2* & 0.158 & 0.0123 & 0.571 \\
\hline & & $\mathrm{Al}-14.3$ pct $\mathrm{B}_{4} \mathrm{C}$ & DA3 & - & 0.0212 & 0.743 \\
\hline
\end{tabular}

*Data from billet that underwent HIP.

and cryomilling of the composite powder. Following degassing, the $\mathrm{H}$ content was reduced to $0.0098 \mathrm{wt}$ pct in the cryomilled $\mathrm{A} 1-7.5 \mathrm{Mg}$ alloy and $0.0123 \mathrm{wt}$ pet in the cryomilled Al-6.4 pet $\mathrm{Al}_{85} \mathrm{Ni}_{10} \mathrm{La}_{5}$ composite; the $\mathrm{O}$ content was, however, not decreased due to degassing and was measured to be $0.328 \mathrm{wt}$ pct in the cryomilled A1-7.5Mg alloy and $0.571 \mathrm{wt}$ pct in the cryomilled Al-6.4 pet $\mathrm{Al}_{85} \mathrm{Ni}_{10} \mathrm{La}_{5}$ composite. The $\mathrm{C}$ content was also not reduced during the degassing process. As discussed later in this article, the changes in $\mathrm{C}, \mathrm{H}$, and $\mathrm{O}$ content during the cryomilling and degassing processes are in good agreement with the thermal analysis data on the evolution of the stearic acid and hydroxide during cryomilling.

\section{E. Grain Growth during Degassing}

While it is important to remove the gaseous content in the cryomilled powder, it is equally important to maintain the initial nanocrystalline structure after degassing. To study the grain growth during degassing, the average grain size of the cryomilled and degassed samples were determined using the XRD line-broadening technique. Following subtraction of the $K_{\alpha 2}$ component and instrumental broadening, separation of the size- and strain-broadening components was performed via approximating the size-broadening profile by a Cauchy function and the strain-broadening profile by a Gaussian function. Under these assumptions, the grain size was calculated using the following equation:

$$
\frac{(\delta 2 \theta)^{2}}{\tan ^{2} \theta_{0}}=\frac{K \lambda}{d}\left(\frac{\delta 2 \theta}{\tan \theta_{0} \sin \theta_{0}}\right)+25\left\langle\varepsilon^{2}\right\rangle
$$

where $\delta 2 \theta$ is the integral breadth in radians, $\theta_{0}$ is the position of the peak maximum, and $\left\langle\varepsilon^{2}\right\rangle^{1 / 2}$ is the rootmean-square lattice strain. The term $d$ is the volumeaveraged grain size and $K$ is a constant taken as 1 . Table II lists the average grain sizes of the different Al materials after cryomilling and degassing. In the case of the Al-6.4 pet $\mathrm{Al}_{85} \mathrm{Ni}_{10} \mathrm{La}_{5}$ sample, the degassed can subsequently underwent hot isostatic pressing (HIP) at $400{ }^{\circ} \mathrm{C}$ for $\sim 4$ hours. Figure 10 shows the grain size distribution in the Al-6.4 pet $\mathrm{Al}_{85} \mathrm{Ni}_{10} \mathrm{La}_{5}$ composite that underwent HIP measured using transmission electron
Table II. Average Grain Sizes for Cryomilled and Degassed Powder, as Determined by XRD

\begin{tabular}{lcc}
\hline Material & Cryomilled (nm) & Degassed (nm) \\
\hline Al-7.5Mg & 30 & 110 \\
Al-6.4 wt pct $\mathrm{Al}_{85} \mathrm{Ni}_{10} \mathrm{La}_{5}$ & 28 & $108^{*}$ \\
Al-14.3 wt pct $\mathrm{B}_{4} \mathrm{C}$ & 25 & 78 \\
\hline
\end{tabular}

*Data from billet that underwent HIP.

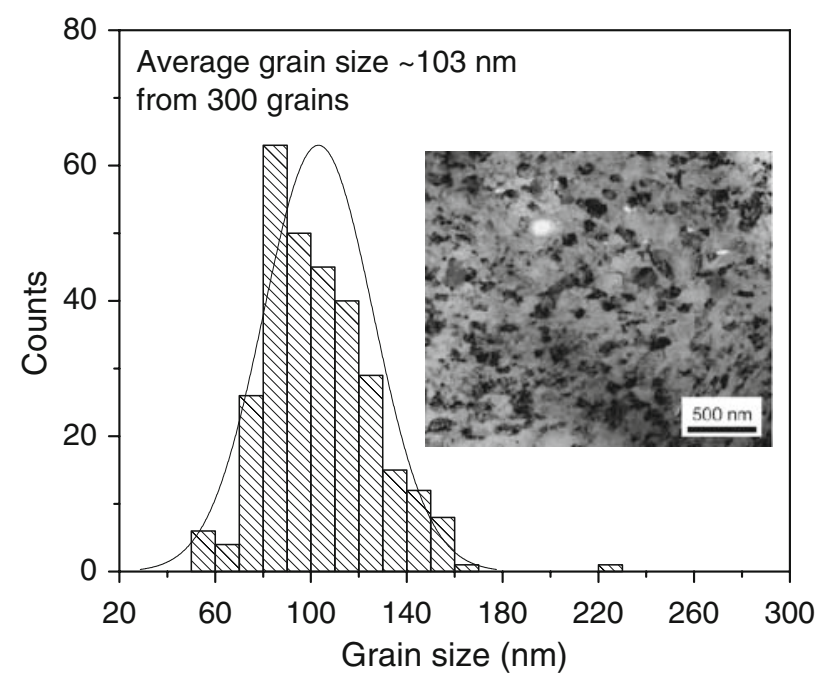

Fig. 10 - Grain size distribution and TEM image of as-hot-isostaticpressed cryomilled Al- 6.4 wt pet $\mathrm{Al}_{85} \mathrm{Ni}_{10} \mathrm{La}_{5}$ composite.

microscopy (TEM). One can see that the TEM result confirms the XRD measurement and the observation that the nanocrystalline structure was maintained after degassing. A detailed study of the microstructural stability is beyond the scope of this article; however, previous studies have shown that the documented thermal stability can be attributed to the grain boundary segregation of the solute or impurity elements ${ }^{[21,22]}$ and the second-phase pinning (nanoscale Al oxide, nitride, carbide, or precipitates ${ }^{[23,24]}$ that were introduced into the Al alloy during the cryomilling processing. 


\section{DISCUSSION}

\section{A. Effect of Cryomilling}

During cryomilling, the powder particles underwent repeated fracture and cold welding, and the newly created fresh surface was protected from exposure to the atmosphere; therefore, cryomilling is expected to redistribute the original surface hydroxides on the atomized powder. This is shown in the low-temperature degassing profile (stage (a)) in the inset of Figure 8(b). According to Litvintsev and Arbuzova, ${ }^{[9]}$ the liberation of physically bonded water occurs in the temperature range up to 140 to $\sim 150{ }^{\circ} \mathrm{C}$. The pressure rise in stage (a) was therefore mainly attributed to the liberation of physisorbed water. The evolution of physisorbed water is apparent in the atomized powder; by contrast, the cryomilled powders showed essentially a flat curve. Note that the starting vacuum level for the $\mathrm{Al}-14.3$ pet $\mathrm{B}_{4} \mathrm{C}$ powder $\left(10^{-7}\right.$ torr $)$ is one magnitude less than that for the Al-6.4 pct $\mathrm{Al}_{85} \mathrm{Ni}_{10} \mathrm{La}_{5}$ powder $\left(10^{-6}\right.$ torr $)$, but the two samples showed a similar plateau throughout the low-temperature range, suggesting that the physisorbed water was greatly reduced on the surface of the cryomilled powder. Cryomilling also affects the evolution of the chemisorbed water and hydrogen, as shown in Figure 8. The gas evolution peak in stage (b), due to the liberation of the chemisorbed water, is significantly lower than that for the atomized powder. In contrast, the gas evolution peak in stage (c), due to the liberation of hydrogen, is significantly higher than that for atomized powder. It should be noted that although the surface hydroxide is reduced in cryomilled powder, the volume hydroxide or oxide is increased (Table I), because the initial hydroxide layer is broken up and fresh surfaces are exposed. Dispersion of hydroxides into the $\mathrm{Al}$ matrix led to changes in the outgassing process for the chemisorbed water. The chemical reactions involved in the outgassing process are ${ }^{[3]}$

$$
\begin{aligned}
\frac{1}{2} \mathrm{Al}_{2} \mathrm{O}_{3} \cdot 3 \mathrm{H}_{2} \mathrm{O} & \rightarrow \frac{1}{2} \mathrm{Al}_{2} \mathrm{O}_{3} \cdot \mathrm{H}_{2} \mathrm{O}+\mathrm{H}_{2} \mathrm{O} \\
\mathrm{Al}_{2} \mathrm{O}_{3} \cdot \mathrm{H}_{2} \mathrm{O} & \rightarrow \mathrm{Al}_{2} \mathrm{O}_{3}+\mathrm{H}_{2} \mathrm{O} \\
\frac{2}{3} \mathrm{Al}+\mathrm{H}_{2} \mathrm{O} & \rightarrow \frac{1}{3} \mathrm{Al}_{2} \mathrm{O}_{3}+\mathrm{H}_{2} \\
\mathrm{Mg}+\mathrm{H}_{2} \mathrm{O} & \rightarrow \mathrm{MgO}+\mathrm{H}_{2}
\end{aligned}
$$

Figure 11 shows the Gibbs free energy for Eqs. [3] through [6] as a function of temperature and pressure. The standard state free energy data are from Reference 7. Reactions [3] and [4] are likely to occur at elevated temperatures or under vacuum. When the hydroxide is embedded in the matrix, Reactions [5] and [6] are kinetically favored. Therefore, one sees a significant decrease in chemisorbed water and a concurrent increase in hydrogen.

\section{B. Effect of Stearic Acid}

The introduction of stearic acid is a second source for the evolution of hydrogen at elevated temperatures
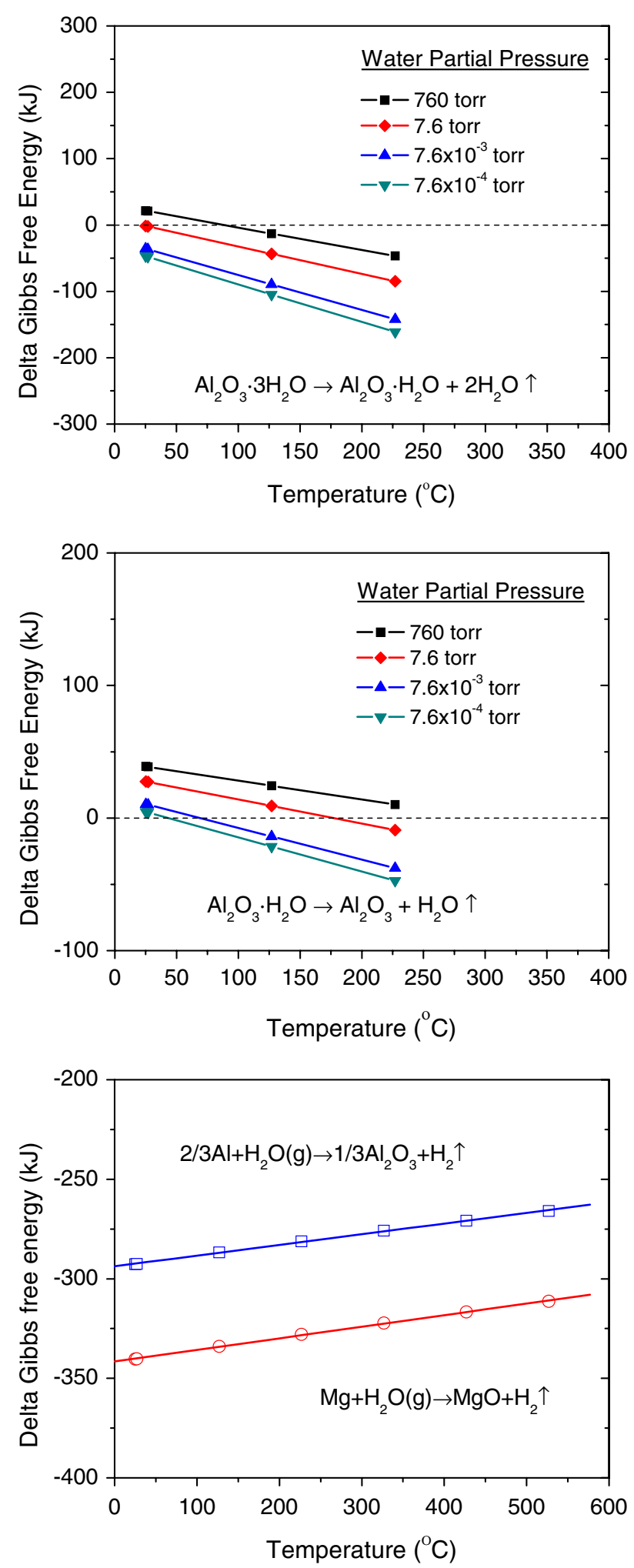

Fig. 11-Free energies of degassing reactions for $\mathrm{Al}$ at different temperatures.

(stage (c)). As mentioned earlier, the TGA results suggest that the stearic acid may react with Al during cryomilling; this is supported by the chemical analysis data in Table I. Figure 12 is a plot of the changes in C, 
$\mathrm{H}$, and $\mathrm{O}$ as a consequence of cryomilling and degassing. The dotted line in Figure 12 indicates the accumulation of $\mathrm{C}, \mathrm{H}$, and $\mathrm{O}$ due to the addition of $0.2 \mathrm{wt}$ pet stearic acid. By using the initial $\mathrm{C}, \mathrm{H}$, and $\mathrm{O}$ content for the starting powder as a reference (i.e., sample M1 is the reference point for samples DM1, M2, and DM2, and sample A1 for samples A2, DA2, and DA3), it is evident that the stearic acid is the primary source of the $\mathrm{C}$ and $\mathrm{H}$ increase in cryomilled powders. Cryomilling caused approximately 0.15 pct $\mathrm{C}$ increment buildup in all cryomilled samples (M2, DM2, A2, and DA2; the C content is not measured in sample DA3 due to the presence of $\mathrm{B}_{4} \mathrm{C}$ ), which is in good agreement with the 0.2 pct stearic acid addition (calculations give a theoretical value of 0.152 pct $C$ increment). Studies ${ }^{[25,26]}$ of Al-C reactions during mechanical alloying indicate that $\mathrm{C}$ atoms form a solid solution and that suitable subsequent annealing $\left(\geq 400^{\circ} \mathrm{C}^{[27]}\right)$ is required to form $\mathrm{Al}_{4} \mathrm{C}_{3}$. In mechanically milled $\mathrm{Al}$ with organic wax addition $\left(\mathrm{C}_{2} \mathrm{H}_{2}-2\left(\mathrm{C}_{18} \mathrm{H}_{36} \mathrm{ON}\right)\right)$, Singer et al..$^{[2]]}$ observed the formation of nanaocrystalline $\mathrm{Al}_{4} \mathrm{C}_{3}(\sim 10 \mathrm{~nm})$ following $500{ }^{\circ} \mathrm{C}$ annealing, but could not find the $\mathrm{Al}_{4} \mathrm{C}_{3}$ compound after annealing at $300{ }^{\circ} \mathrm{C}$. These results suggest that if the hydrogen in the organic processcontrol agent is properly outgassed, the remaining $\mathrm{C}$ atoms can form nanocrystalline dispersoids $\mathrm{Al}_{4} \mathrm{C}_{3}$, which will strengthen the mechanically milled $\mathrm{Al}$ alloy. The measured hydrogen increment in samples cryomilled using commercially pure Al follows the theoretical calculations but is slightly higher in samples cryomilled using the $\mathrm{Al}-7.5 \mathrm{Mg}$ alloy. This is probably due to a slight pickup of moisture in the glove box. As shown in Figure 11, the partial pressure for the adsorption of water to the Al surface is approximately $10^{-6} \mathrm{~atm}$; this approximately corresponds to the marginal moisture reading of $\sim 1 \mathrm{ppm}$ in our glove box. The addition of $\mathrm{Mg}$ may lead to a decrease in the required partial pressure, due to its higher activity relative to that

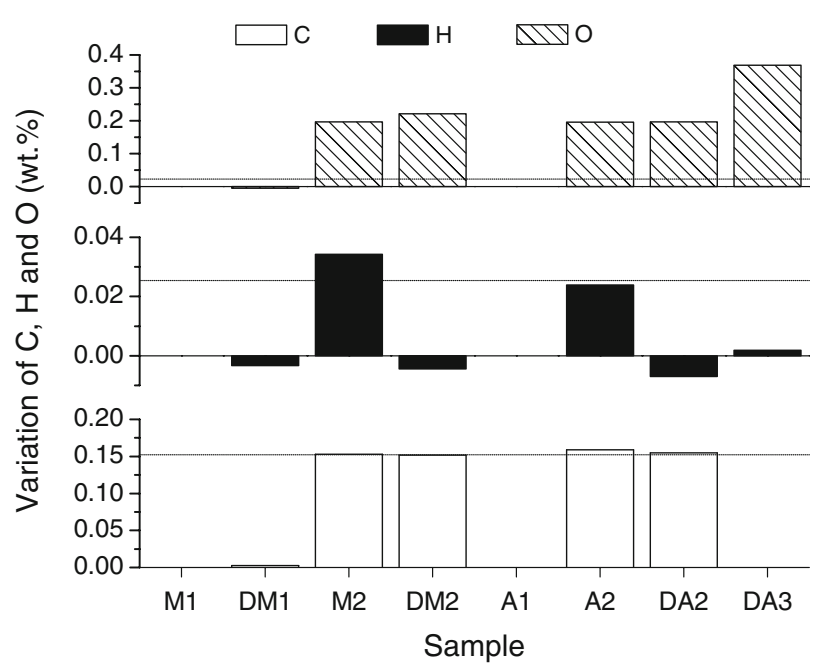

Fig. 12-Variations in $\mathrm{C}, \mathrm{H}$, and $\mathrm{O}$ content with alloy composition and cryomilling condition. Dotted line indicates amount of $\mathrm{C}, \mathrm{H}$, and $\mathrm{O}$ introduced from stearic acid. Sample identification in the $x$-axis is given in Table I. of Al. Following degassing, the $\mathrm{H}$ content is lower than that in the atomized powder, suggesting that the $\mathrm{H}$ introduced due to stearic acid addition was essentially removed during degassing. Cryomilling also caused the accumulation of $\sim 0.2$ pct $\mathrm{O}$. This incremental value is comparable to the initial $\mathrm{O}$ content in the atomized powder (Table I), suggesting that the $\mathrm{O}$ buildup may be caused by reformation of the oxide layer on the cryomilled powder surface. However, the $\mathrm{O}$ buildup caused by cryomilling is much higher in the $\mathrm{B}_{4} \mathrm{C}$ composite powder, as evidenced by its larger specific area (Figure 9).

\section{CONCLUSIONS}

1. The organic process-control agent (i.e., $0.2 \mathrm{wt}$ pct stearic acid) was the primary source for introducing $\mathrm{H}$ and $\mathrm{C}$ into cryomilled Al. During degassing, the $\mathrm{C}$ was retained in the cryomilled powder and the stearic acid was not outgassed in molecular form. The $\mathrm{H}$ introduced from stearic acid was essentially removed at a temperature of approximately $400{ }^{\circ} \mathrm{C}$.

2. In comparison to the behavior for gas atomized $\mathrm{Al}$, the evacuation of chemisorbed water in cryomilled Al was impeded and, instead, the cryomilled Al showed a strong hydrogen release peak.

3. The cryomilled Al powder showed good thermal stability during degassing, and bulk nanostructured Al (average grain size $\sim 100 \mathrm{~nm}$ ) was consolidated using conventional PM techniques.

\section{ACKNOWLEDGMENTS}

Research was sponsored by U.S. Army Research Laboratory (ARL) and was accomplished under Cooperative Agreement W911NF-08-2-0028. The views and conclusions made in this document are those of the authors and should not be interpreted as representing the official policies, either expressed or implied, of ARL or the US Government. The US Government is authorized to reproduce and distribute reprints for Government purposes notwithstanding any copyright notation hereon.

\section{OPEN ACCESS}

This article is distributed under the terms of the Creative Commons Attribution Noncommercial License which permits any noncommercial use, distribution, and reproduction in any medium, provided the original author(s) and source are credited.

\section{REFERENCES}

1. D.B. Witkin and E.J. Lavernia: Progr. Mater. Sci., 2006, vol. 51, pp. $1-60$.

2. A.P. Newbery, S.R. Nutt, and E.J. Lavernia: JOM, 2006, vol. 58, pp. 56-61. 
3. Y.W. Kim, W.M. Griffith, and F.H. Froes: J. Met., 1985, vol. 37, pp. 27-33.

4. J.R. Pickens: J. Mater. Sci., 1981, vol. 16, pp. 1437-57.

5. J.C. Ehrstrom, E. Andrieu, and A. Pineau: Scripta Metall., 1989, vol. 23, pp. 1397-1400.

6. J.L. Estrada and J. Duszczyk: J. Mater. Sci., 1991, vol. 26, pp. 4203-07.

7. I. Barin, F. Sauert, E. Schultze-Rhonhof, and S.S. Wang: Thermochemical Data of Pure Substances, VCH, New York, NY, 1993.

8. B.E. Hayden, W. Wyrobisch, W. Oppermann, S. Hachicha, P. Hofmann, and A.M. Bradshaw: Surf. Sci., 1981, vol. 109, pp. $207-20$

9. A.I. Litvintsev and L.A. Arbuzova: Powder Metall. Met. Ceram., 1967, vol. 6, pp. 1-10.

10. L. Ackermann and R. Lalauze: in High Strength Powder Metallurgy Aluminum Alloys II, G.J. Hildeman and M.J. Koczak, eds., TMS-AIME, Warrendale, PA, 1986, pp. 175-91.

11. V. Chiavazza, M. Pijolat, and R. Lalauze: J. Mater. Sci., 1988, vol. 23, pp. 2960-64.

12. L. Kowalski, B.M. Korevaar, and J. Duszczyk: J. Mater. Sci., 1992, vol. 27, pp. 2770-80.

13. J.L. Estrada, J. Duszczyk, and B.M. Korevaar: J. Mater. Sci., 1991, vol. 26, pp. 1631-34.

14. S.J. Davis, A.P. Miodownik, and J.F. Watts: J. Mater. Sci., 1995, vol. 30 , pp. 3811-19.
15. J.B. Fogagnolo, F. Velasco, M.H. Robert, and J.M. Torralba: Mater. Sci. Eng. A, 2003, vol. 342, pp. 131-43.

16. Z.H. Zhang, B.Q. Han, K.H. Chung, and E.J. Lavernia: Metall. Mater. Trans. A, 2006, vol. 37A, pp. 2265-73.

17. M. Hasegawa and M.J.D. Low: J. Coll. Interface Sci., 1969, vol. 30 , pp. $378-86$.

18. D.L. Allara and R.G. Nuzzo: Langmuir, 1985, vol. 1, pp. 52-66.

19. M.S. Lim, K. Feng, X.Q. Chen, N.Q. Wu, A. Raman, J. Nightingale, E.S. Gawalt, D. Korakakis, L.A. Hornak, and A.T. Timperman: Langmuir, 2007, vol. 23, pp. 2444-52.

20. R. Lalauze, I. Guillemin, and C. Pijolat: J. Thermal Analysis, 1986, vol. 31, pp. 1109-19.

21. A. Michels, C.E. Krill, H. Ehrhardt, R. Birringer, and D.T. Wu: Acta Mater., 1999, vol. 47, pp. 2143-52.

22. T.R. Malow and C.C. Koch: Acta Mater., 1997, vol. 45, pp. 2177 86.

23. F. Zhou, J. Lee, and E.J. Lavernia: Scripta Mater., 2001, vol. 44, pp. 2013-17.

24. B.Q. Han, Z. Zhang, and E.J. Lavernia: Phil. Mag. Lett., 2005, vol. 85 , pp. $97-108$

25. Y. Zhou and Z.Q. Li: J. Alloys Compd., 2006, vol. 414, pp. 107-12.

26. M.H. Enayati, M. Seyed-Salehi, and A. Sonboli: J. Mater. Sci., 2007, vol. 42, pp. 5911-14.

27. R.F. Singer, W.C. Oliver, and W.D. Nix: Metall. Trans. A, 1980, vol. 11A, pp. 1895-1901. 